\title{
Decentralisation and local governance in Mozambique: the challenges of promoting bottom-up dynamics from the top down
}

\author{
Roberta Holanda Maschietto \\ Centre for Social Studies, University of Coimbra
}

\begin{abstract}
Since the conclusion of the peace accords in 1992, Mozambique has undergone several changes in the field of governance and institutionbuilding. One key aspect of such reforms, strongly promoted by donors in peace-building contexts, has been the agenda of decentralisation and local governance, which has entailed political devolution in selected municipalities, and deconcentration and the creation of local councils in the rural districts. This article examines this agenda and its implementation focusing on two domains. First, it discusses the different interests that have shaped the political decisions taken on this agenda at the national level. Second, it examines the case of the local councils in the district of Angoche, critically debating the extent to which they epitomise the increase of local representativeness and, thus, whether or not they enhance bottom-up dynamics of governance. I argue that the limited effectiveness of such reforms in Mozambique reflect the inherent contradiction between the strong top-down dynamics that shape this process and the bottom-up effects that it aims to promote.
\end{abstract}

\section{KEY WORDS}

Mozambique; peace-building; decentralisation; local governance; local councils

\section{Introduction}

Decentralisation and local governance have been at the centre of peace-building activities promoted by Western donors in the last two decades. In the mainstream discourse, these agendas have been linked to the enhancement of democracy, good governance, local empowerment and poverty reduction, all factors perceived as contributing to sustainable peace. To a great extent, these expected results and the perceived legitimacy attached to these reforms stem from the understanding that decentralisation and local governance enhance local representation in governance matters. This article is concerned precisely with this assumption: it discusses the implementation of decentralisation and local governance policies in Mozambique by questioning the extent to which they have enhanced local representation.

In this regard, it first examines the domain of policy formulation and the conflict of interests informing the design and implementation of the agenda of decentralisation in 
Mozambique. Second, it explores the constitution of the local councils and the relationship between these bodies and the local constituencies they are supposed to represent. The analysis shows that the contradictions that have shaped the design and implementation of decentralisation in Mozambique had the double and paradoxical function of both allowing and preventing change at the same time. That is, whereas the government has formally adopted the agenda of decentralisation, partly in response to the pressure of international donors, the specifics of the agenda and the way it has been implemented have ultimately hindered a more substantial change in the national political landscape. At the national level, this has led to a preference for administrative deconcentration instead of political devolution to local state units. At the local level, this has led to very little change in terms of people's empowerment, as these reforms have not necessarily fomented the development of critical political consciousness at the local level nor resulted in a significant increase of local demand for participation in governance issues.

This analysis is developed in three main sections, besides the introduction and conclusion. The first section examines the rationale behind the promotion of decentralisation and local governance in peace-building contexts in general and in Africa in particular. The second section discusses the Mozambican case by exploring how decentralisation entered the agenda and how the policy was designed (and redesigned) in such a way as to accommodate the different perspectives that existed within the government, while still favouring the status quo of the dominant party. The third section critically examines the creation of the local councils and these bodies' interactions with the local community they are deemed to represent, in particular in the northern district of Angoche. The final section resumes the argument, while comparing the local councils with another kind of community body, called the local development committees, in the same district. The argument presented is that the effectiveness of decentralisation and local governance reforms in Mozambique have been hindered by the inherent contradiction that exists between the strong top-down dynamics that have shaped this process and the bottom-up effects that it aims to promote. At the same time, the structural context surrounding these reforms has also negatively affected the effectiveness of alternative expressions of bottom-up governance.

The findings in this article constitute part of a broader research project discussing empowerment promotion in Mozambique and the case of the District Development Fund. ${ }^{1}$ The empirical data used in the analysis was gathered during fieldwork in Mozambique between March and June 2012, and includes a total of 18 semi-structured interviews and 17 focus groups (of 3-15 people) with members of the local councils, rural citizens in different communities of the district of Angoche (men and women), as well as employees in the district administration and in the provincial government of Nampula who followed the constitution and work of the local councils.

The focus on the province of Nampula, and on the district of Angoche in particular, is justified by this region's history in the realm of local governance in Mozambique. Nampula was a pioneer in implementing practices of decentralised planning and participatory approaches in the early 1990s, which culminated in the so-called 'Nampula pilot'-the Local Development Fund Programme in Nampula Province-later used as a basis for a broader national programme. Angoche was one of the four districts where these experiments first took place and where the first local councils were created. In this research I presumed that this background would enhance the chances of success of the councils in Angoche, in 
comparison to other districts-a matter that I discuss in the conclusion, where I relate the case of Angoche to other districts.

\section{Decentralisation and local governance in peace-building contexts}

Before discussing decentralisation and local governance in peace-building contexts, it is important to clarify the meaning of these concepts. There are many definitions of decentralisation, but it broadly refers to the transfer (concomitantly or separately) of responsibilities, resources, accountability and institutions from the central government to sub-national entities. ${ }^{2}$ For the purposes of clarity, the literature differentiates between two main types of decentralisation processes. One the one hand, there is devolution (or democratic decentralisation), which refers to the 'transfer of power and resources to sub-national authorities that are both (relatively) independent of central government and democratically elected'; and, on the other hand, there is deconcentration (or administrative decentralisation), which refers to the 'transfer of authority to sub-national branches of the central state, often to line ministry officials based in local areas. ${ }^{3}$ As discussed below, in Mozambique decentralisation has consisted of both the devolution of political power to selected municipalities and the deconcentration of administrative responsibilities to the provinces and districts.

Local governance broadly refers to the extent to which power and authority are exercised at the local level. ${ }^{4}$ It should be noted that by this definition alone, and if no specific context is provided, local governance may include anything from local councils to community groups, as well as warlord fiefdoms or other types of community enclaves that represent the interests of a minority only. ${ }^{5}$ A central factor to consider is, thus, the extent to which the arrangement of local governance is legitimate. In the current international mainstream discourse, local governance is used to highlight the ability that legitimate local actors, and civil society in particular, have to influence governance. A priori, decentralisation and local governance have the potential to reinforce one another, but ultimately they refer to different processes. In Mozambique, one of the main national attempts to promote local governance was through the creation of local councils.

In this article, peace-building is understood as a long-term process that follows the signing of a peace accord and that aims to address the long-term relationship between conflicting parties and the structural issues that have contributed to the triggering of direct violence. ${ }^{6}$ In the current context, the mainstream peace-building paradigm is based on the ideal of the liberal peace, having as its main pillars the institution and consolidation of democracy, economic liberalisation and human rights. ${ }^{7}$ As decentralisation and local governance have been regarded as tools to deepen these pillars, they have also become embedded in the peace-building agenda, being at the centre of the institutional reforms pursued by international actors in these contexts. ${ }^{8}$

The extent to which decentralisation and local governance contribute to peace-building is a matter of huge debate that is, nevertheless, not very systematised. ${ }^{9}$ On the one hand, there is a literature that focuses on decentralisation and local governance and their effect in conflict mitigation. ${ }^{10}$ On the other hand, there is a literature that discusses these agendas in the context of peace-building and state-building reforms, where the emphasis is on the general benefits expected from decentralisation, in particular, in the realm of good governance, the deepening of democracy, and the promotion of local empowerment and poverty reduction. ${ }^{11}$ In both cases, however, different studies have reached different conclusions; 
moreover, in-depth comparative empirical studies able to provide more solid conclusions are still lacking. ${ }^{12}$

To a large extent, the call for decentralisation and local governance in peace-building scenarios is justified by the perception that more localism means more legitimacy and better democracy. Indeed, according to the international mainstream policy discourse, decentralisation and local governance have the potential to foster good governance by bringing the state closer to the local constituencies. By doing so, decentralisation is expected to lead to greater political participation at the local level, 'with citizens more able to make claims on local government and to subject it to greater scrutiny', thus enhancing downward accountability, reducing levels of corruption and leading to greater responsiveness to the poor. ${ }^{13}$ More recently, decentralisation has also been linked to poverty reduction, and as a means to promote local empowerment as well achieving the Millennium Development Goals. Decentralisation is perceived to contribute to poverty reduction precisely because resources are allocated locally, therefore giving the grassroots more control over this process and thus enhancing local ownership. ${ }^{14}$

It should be noted that the specific domain of decentralisation considered in the current mainstream policy agenda is political devolution, and not deconcentration. There is an understanding that 'decentralized governance provides a structural arrangement and a level playing field for stakeholders and players to promote peace, democracy, and development', ${ }^{15}$ which means that decentralisation has a great potential to redistribute power resources (political and economic) across different layers of society. More generally, it is the domain of local representation and empowerment that provides the legitimacy of these agendas.

Despite this optimistic discourse, the existing evidence for a correlation between decentralisation/local governance reforms and peace, poverty reduction and good governance is thin, to say the least. ${ }^{16}$ In Africa, in particular, there have been serious limitations in the extent to which such reforms have promoted democratisation and poverty reduction. ${ }^{17}$ Contrary to the idealised model, several patterns have emerged that compromise the expected success of decentralisation reforms, including, among others, incomplete statutory reforms, deviation or recapturing of resources by central agents, poor capacity of local councils, and the continued domination of elites via the direct use of local organs or their control behind the scenes. ${ }^{18}$ Indeed, in several instances, decentralisation has actually 'reinforced the power of local elites and has worsened spatial inequalities.' ${ }^{19}$

In a comparative study of African cases of decentralisation and its effects in poverty reduction, Crook noted that 'the degree of responsiveness to the poor and the extent to which [decentralisation has] any impact on poverty are determined primarily by the politics of local-central relations and the general regime context-particularly the commitment of the central political authorities to poverty reduction. ${ }^{20}$ Consequently, even though in many cases decentralisation reforms have indeed contributed to an increased level of participation, this has not necessarily translated into policies that were more responsive to the poor. On the contrary, in some cases, these processes became elite driven. Reviewing several worldwide studies on this matter, Crawford and Hartmann also noted that in most of Africa the correlation between decentralisation and poverty reduction was actually negative; in a 2014 report, Jackson reached the same conclusion. ${ }^{21}$

There are many explanations for these poor results. First, post-war scenarios generally lack human and material resources to implement these reforms efficiently. ${ }^{22}$ Second, there are problems linked to existing institutional and social practices: in peace-building scenarios 
where state institutions are weak and ineffective, they may become the locus for elite manipulation in order to sustain and gain more power through the mechanism of clientelism. ${ }^{23}$ This scenario is further compounded by the absence of a strong civil society and their direct engagement in these processes, as well as by the existing democratic deficit. ${ }^{24}$

These problems are usually intensified in the context of post-colonial states, where there is often a mismatch between the Western rationale that frames decentralisation reforms and the logic that sustains state-society relations in non-Western contexts. In Africa, in particular, the coexistence of formal Westernised states and traditional societies strongly affects the outcome of such reforms, often by reinforcing the political and contentious aspects of those reforms. This feature implies that any process of power redistribution may suffer strong resistance not only at the central level, but also at the local level. ${ }^{25}$ In this regard, decentralisation entails not only the linear and technical implementation of reforms but also, more fundamentally, a change of mentality among local actors, notably with regard to how they relate to the state.

This is further connected to a key issue, which is the (lack of) existing political will to implement these reforms, not only among the political elite, but also among local actors, in particular those who stand between the central government and the local population-a factor that also affects the chances of these reforms improving downward accountability. ${ }^{26}$ In practice, lack of political will may lead to cycles of decentralisation and re-centralisation, where donors push for reforms, while national actors resist them by adopting only partial or parallel measures that ultimately annul the expected effect of the reforms. ${ }^{27}$ This may further influence the sequencing of the different types of decentralisation reforms, which, in turn, also leads to different results in terms of local empowerment, democratic governance and participation. ${ }^{28}$

The remainder of this article considers these problems in the case of Mozambique. The next section explores the issue of political will and conflicting interests that marked the definition of the national agenda on decentralisation. The following sections focus on the discussion about local representation and legitimacy through the analysis of the local councils in the district of Angoche.

\section{Decentralisation in Mozambique: defining the agenda}

One of the biggest challenges to decentralisation in Mozambique has been the legacy of centralism. Mozambique became independent from Portugal in 1975. While different movements engaged in the anti-colonial struggle, by the time of independence they had merged into one, the Mozambique Liberation Front-Frelimo, which became the first and only existing party in the country in the years to come. Despite the different ideological perspectives that existed within Frelimo, its radical faction became increasingly dominant and in 1977 the party formally embraced a Marxist-Leninist agenda. This turn, combined with Frelimo's support to the liberation movement in Southern Rhodesia and the African National Congress in South Africa, sparked strong regional reactions.

Renamo-Mozambique's National Resistance-was born in this context. Originally created to be a column to spy on Zimbabwean guerrillas based in Mozambique in the mid1970 s, it soon became a destabilisation machine sponsored by the apartheid government of South Africa to crush the government of Frelimo. Having no clear political agenda in its early years, Renamo built its own identity in opposition to what Frelimo represented, and 
only towards the end of the war, when peace negotiations were under way, did Renamo invest in its transformation into a political party. Therefore, and even though Renamo gained important support during the war, particularly in the central region of the country, when peace came Frelimo was still the dominant national political force. More importantly, Frelimo had 17 years of experience as a unique, strong, centralised and extremely organised and hierarchic ruling party, whereas Renamo was still in the midst of a complex transition from a guerrilla movement into a political party.

Decentralisation was introduced in Mozambique in the context of the institutional reforms that followed the 1992 Peace Accords. At the structural level, it was a response to the need for stabilisation, which required the creation of political space for Renamo, and the need for economic recovery accompanying the gradual transition to a market economy. ${ }^{29}$ Decentralisation was also perceived as a means to understand more deeply the local aspects that had contributed to the war, in particular local support for Renamo, thus constituting an effort by the government to get closer to the rural population. ${ }^{30}$

Notably, the discussion about decentralisation took place concomitantly with the first national attempt to bring the traditional authorities back onto the political agenda. After independence, Frelimo took a harsh stance towards these actors, who were perceived as standing in the way of modernisation and corrupted by colonialism. Yet, as peace negotiations were under way, the realisation that traditional authorities were an important part of peace led to a shift in the government approach to these actors. ${ }^{31}$ Between 1991 and 1997 a series of studies were conducted by a team in the Ministry of State Administration, investigating how kin-based institutions could play a role in post-war nation state reformation, democratisation and decentralisation. The results of this research led to a shift in the discourse, whereby traditional authorities were now recognised as legitimate actors and truly representative of the communities. ${ }^{32}$ The culmination of this process was Decree $15 / 2000$, which recognised three categories of what are now called 'community authorities' - 'traditional chiefs', former Frelimo 'secretaries of suburban-quarters or villages' and 'other leaders legitimised as such by the respective local communities'-who perform the double role of representatives of rural communities and assistants of the state. ${ }^{33}$ As will be discussed below, this development had an important influence on the constitution and functioning of the local councils later on.

Overall, the various actors involved in the process of decentralisation had different views about the specifics of this agenda, in particular regarding the design and pace of these reforms. ${ }^{34}$ Frelimo reformers emphasised the need for decentralisation because of its link with democratisation and the enhancement of state responsiveness at the local level. The introduction in the 1990 constitution of the concepts of local power and participation gave them hope that a new governance model could be implemented, and, indeed, two months before the first multiparty elections, the first law on devolution (3/94) was approved. The law was quite radical and called for elections of all the presidents of the municipal councils, the district administrators and district and municipal assemblies in the country. Elections were scheduled for 1996, and were supposed to cover all 128 districts and 13 urban zones.

The approval of this law should be contextualised. One of the key figures behind its elaboration was Aguiar Mazula, Minister of State Administration between 1990 and 1994. Mazula was part of a small group of reformers that included selected members of Frelimo's Central Committee and who met 'clandestinely' to discuss alternatives to the centralised state. ${ }^{35}$ He was also part of the delegation that discussed the peace accords in Rome and used this 
channel to introduce some of his innovative ideas about democratisation in Mozambique. Yet, Mazula did not represent the dominant faction inside Frelimo. In fact, decentralisation had not even entered the peace accords. Hence, as much as it was surprising that such a radical law was approved in 1994, it was not unexpected when the different actors started to contest it.

Indeed, when it came to its implementation, Renamo questioned the process of devolution envisaged in the legislation and became actively engaged in the formulation of a constitutional amendment. ${ }^{36}$ Frelimo found itself torn between pro-reformists and the conservatives who wanted to reduce the pace of the reform. ${ }^{37}$ Ultimately, Frelimo pro-reformists had to yield to the conservative majority and the orientations of the party's political committee. ${ }^{38}$ An important factor influencing such an outcome was the results of the first multiparty elections in 1994, which showed unexpected support for Renamo in the centre and north of the country, in particular in the rural areas. Such results enhanced Frelimo's fear of a major setback in the municipal elections scheduled for 1996 and the potential loss of political control in important parts of the country. ${ }^{39}$ Yet, Frelimo was also facing strong pressure from important donors, such as the World Bank and the German Technical Co-operation Agency (GTZ), which had been supporting several projects linked to decentralised planning since the early 1990 s at the provincial and district levels. ${ }^{40}$ Consequently, the legislative outcome on decentralisation reflected a form of compromise between these different actors. First, in November 1995 the new multiparty assembly declared the devolution law unconstitutional. Then in 1996 a constitutional amendment was passed (Law 9/1996), which cemented a bifurcated system of local government, ${ }^{41}$ partially withdrawing the decentralisation agenda.

Essentially, the amendment created a parallel system of local governance: on the one hand, there are urban municipalities, with devolved powers, mayors and Municipal Assemblies elected every five years and their own revenue system; on the other hand, there are deconcentrated local state agencies of the central state (provinces and districts), which have their main political representatives appointed by a superior administrative echelon. This means that in Mozambique there are two levels of subordination, both technical and political: the provinces and the districts have representatives directly appointed by the party, who are accountable to the central government, whereas the municipalities have devolved autonomous powers, competencies and resources. ${ }^{42}$ At the same time, the municipalities are also partially subordinated to the provinces.

The combination of these two structures translates into the 'gradual' approach to decentralisation in Mozambique, which foresees the progressive transformation of the villages and localities into municipalities, as well as the progressive transfer of extra functions and resources from the central state to the latter. Gradualism is justified as an approach that takes into account 'lessons learned' from the process as it is implemented; nevertheless, some analysts interpret this option as the only viable compromise inside Frelimo on the matter. ${ }^{43}$

The reversal of the first law came as a huge disappointment to many inside the government. By 1999, many technocrats were pushing for a more radical process, focusing on the district as the basic level of administrative management. They tried to include the topic on the political agenda before the start of the new mandate of president Chissano, but faced strong resistance from the technocrats who were linked to the political sector of the government. ${ }^{44}$ Surprisingly, Renamo voted with Frelimo in favour of the dual system even though a more radical agenda could have provided more space for the opposition's consolidation as 
a political player in the country. Moreover, when municipal elections took place, Renamo repeatedly boycotted them. This posture, ultimately, contributed to the strengthening of Frelimo as a dominant party instead of creating space for alternative political actors.

Because of these developments, the outcome of decentralisation in Mozambique has been the opposite of what was expected by those who pushed for it, in particular donors, whose official concern was the 'strengthening of civil society' and the attenuation of the 'excessive and imposing' role of the state. ${ }^{45}$ In practice, the gradual approach and the emphasis on deconcentration instead of devolution has largely hindered such outcomes, contributing instead to the consolidation of Frelimo as a dominant political force, by enhancing the control that the party has at the local level. This system moreover turned out to be quite complex and contradictory in its operation, often leading to conflicts of authority between the representatives appointed by the government (at the provincial and district level) and the elected mayors in the municipalities. ${ }^{46}$

This state of affairs highlights the problem of the disjunction between what is usually expected from decentralisation and what takes place in practice. The Mozambican case shows that centralising tendencies are not incompatible with the process of decentralisation. In fact, the selection of the format of this process says a lot about its potential to distribute or concentrate power. On this, it should be noted that since they first took place, in 1998, municipal elections have been extremely contested and often won by opposition parties (Renamo, and, more recently, the Democratic Movement of Mozambique-MDM). ${ }^{47}$ This raises the question of how much power Frelimo could lose territorially in the case of a more radical process of devolution, as envisaged in the first version of the law.

More recently, the agenda of decentralisation has also been highly contested by Renamo, in the context of the resumption of conflict in the last couple of years. Following the 2014 elections for the presidency and provincial assemblies, Renamo's leader Afonso Dhlakama has called for a revision to the agenda of decentralisation, proposing a bill for more autonomous provincial governments, whereby the provincial governor position would stay as it is (nominated by the president), but there would also be an elected 'council president. This hybrid arrangement would allow Renamo to have more influence in the provinces where it gained a majority in the provincial assemblies. ${ }^{48}$ As the negotiations on this and other matters are taking place, Dhlakama has regularly threatened to govern by force in those provinces where Renamo won the majority of seats in 2014. Whereas Dhlakama's actions have been driven by a series of motives that are not in keeping with the idea of comprehensive democratic reform in Mozambique, the current standstill is a blatant reminder of how the agenda of decentralisation touches on profound issues of power that have not yet been resolved despite 20 years of peace.

\section{Instigating bottom-up governance dynamics: local councils and representativeness in Angoche}

The principle of gradualism dictates that the number of municipalities in Mozambique will progressively increase. Currently, there are 53 municipalities in Mozambique (the last 10 were created in 2013, when the last municipal elections took place). In contrast, there are 151 districts, of which 13 were also created in $2013 .{ }^{49}$ As explained above, unlike the municipalities, the districts have a representative (the district administrator) directly appointed 
by the province. At this level there is no mechanism of direct popular representation, or an equivalent of the municipal assemblies. What do exist, instead, are local councils.

The local councils (LCs) were formally introduced in Law 8/2003, but their implementation took place systematically only in 2006, along with the introduction of the Local Initiative Investment Budget-the first mechanism that poured money from the central government directly into the districts. ${ }^{50}$ These bodies, as they function today, were largely inspired by a series of participatory exercises carried out in the 1990s, in co-ordination with Western donors in selected provinces in Mozambique. It was within one such early project, the Local Development Fund Programme in Nampula Province, ${ }^{51}$ that the first local councils were created. ${ }^{52}$

At the national level, the 2005 regulation of local state organs defined the local council as 'an organ of consultancy of the local administration authorities, in search of solutions for fundamental matters that affect the lives of the population, their well-being and sustainable development. ${ }^{53}$ Their function is that of 'guaranteeing the communities' participation in the conception and implementation of the economic, social, and cultural programs that contribute to local development, ${ }^{54}$ and they should be established at the different levels of the districts' subunits. ${ }^{55}$

The LCs should be comprised of prominent people in the communities, such as 'community authorities, representatives of interests groups of an economic, social, and cultural nature chosen by the LCs or forum of a lower echelon in proportion to the population of each territorial rank. ${ }^{56}$ In order to ensure their bottom-up character, they are initially constituted at the lower level of the villages, the smaller subunit within the districts. A further selection process internal to the village councils follows, in order to choose those who will belong to the LCs at the upper levels of the district's subunits (the localities, the administrative posts and, finally, the district). The idea is to create a chain of communication so that the voices of each and every community may reach the district administration.

Chronologically, the councils were created after the Decree that instituted the community authorities. In this regard, the logic of their functioning is intimately linked to the understanding that these authorities are representative of the local communities, even though they are not the only members of the councils. Also, an important feature of the LCs is that, even though they are often depicted as the 'civil society' in the districts, they are in fact hybrid institutions, which have a local government representative as president. At the district level, which is the highest instance of the LCs, the president is the district administrator. The presence of such authorities is justified by the president's role as an instrument of 'articulation' between the community and the local government and the fact that, ultimately, the executive function belongs to the administrator. More generally, this role of articulation pervades the whole functioning of the LCs, as well as of the community authorities. ${ }^{57}$

In practice, as discussed below, this double function causes confusion regarding the role of these actors rather than helping to promote local governance and representativeness. This situation is further compounded by the problematic process that led to the selection of the community authorities - a process based mostly on competing claims of authority, which did not necessarily represent local interest ${ }^{58}$ - and by the very process that led to the constitution of the local councils, to which I now turn. 


\section{The local councils' constitution: who choses whom?}

An important indicator of local representativeness relates to how the councils were constituted and the extent to which the local population they are deemed to represent took part in this process. As noted above, in the district of Angoche the first LCs were created during a project that took place in Nampula in co-ordination with donors in the 1990s. With the introduction of national legislation for local state organs, these existing councils had to be reconstituted, a process that took place between 2006 and 2007. Despite previous experience with this process, the reconstitution faced several limitations with regard to its bottom-up format: as some early members recalled, at that stage they were not voted on by the community, instead, they were chosen by community authorities. ${ }^{59}$

In 2011, a major process of reconstitution of the LCs took place nationally, largely driven by the recognised need to improve these bodies' representativeness and inclusiveness. In Angoche, this 'revitalisation', as it was called, was organised and monitored by the district's technical commission (DTC). As explained by DTC members, a week before the selection process they sent a notice to the chiefs of each district's administrative post so that they could inform the localities, the régulos (high echelon local authorities) and the village chiefs about the event, so the latter could mobilise the communities to take part in it. When the DTC arrived, people were gathered to, first, choose the LC members at the village level, and then, these members would proceed to the localities where some of them would be selected for the LCs at the upper levels. ${ }^{60}$ The evidence from the fieldwork showed that this process turned out to be problematic with regard to its ability to ensure genuine local representation, in particular the inclusiveness of the LCs.

When describing the process, the new LC members frequently used the words 'elected', 'voted' and 'chosen', often interchangeably, to describe how they had been selected. ${ }^{61}$ However, after further enquiry, it became evident that this process had different meanings, including aspects of voting, invitation/appointment and volunteering sometimes mixed in different orders. Whereas some members reported having 'volunteered' for the post, ${ }^{62}$ or being selected directly by the community in an open process, ${ }^{63}$ in many cases chosen members referred to an informal pre-selection phase, where they had been called privately by local chiefs, and invited or asked to be part of the 'selection process. ${ }^{64}$

The council members were unanimous in their reference to the community's awareness of and participation in this process. Yet, if by 'the community' we understand the everyday people living in the villages, it was never clear what proportion of villagers were present at the time. Reports from the DTC refer to participation numbers ranging from 17 to 239 at each locality ${ }^{65}$ which are much reduced numbers if we consider the district population of 276,471 people and its 14 localities. ${ }^{66}$ Moreover, these nominal values say little about the quality of participation and the general dynamics that preceded the presence of the DTC.

Remarkably, reports from DTC members pointed to the limitations of trying to implement a horizontal model of participation at the local level. Despite some positive evaluations, in particular when comparing the 2011 process with the previous one, ${ }^{67}$ several members admitted facing important constraints that have jeopardised the quality of the councils' reconstitution. Confirming the findings from the focus groups, some members recognised their lack of control of the procedures that preceded the arrival of the teams in the villages and localities. As the visits were pre-scheduled, when they arrived everything was set up and some had the feeling that people had been pre-selected, even though that was not the 
original agenda. ${ }^{68}$ One interviewee admitted feeling that they went there basically to legitimate the process and not to make it happen. ${ }^{69}$

One DTC member noticed that, when they arrived in the villages, they called for everyone to participate including members of other political parties (non-Frelimo). However, local leaders told them on several occasions that members of the opposition did not want to participate. He sensed that the régulos had become linked to 'the party', in the view of the population, curbing the willingness of other parties to take part in the process. ${ }^{70}$ In one village they even had to schedule a new voting process so opposition parties could participate, but unfortunately, most of the time, the DTC did not pursue this issue further. Why this verification of the process through rescheduling voting was not done comprehensively is a crucial question. One could hypothesise that the process was, indeed, a mere legitimisation of local power politics in favour of Frelimo as some authors have argued in other case studies. ${ }^{71}$ One of the DTC members admitted that most of the people chosen for the LC were in fact trusted members of the party. ${ }^{72}$ While this political aspect appeared in some of the responses in the fieldwork, the data gathered did not allow for a direct correlation that could sustain this hypothesis, but it highlighted that this is an issue worth investigating more systematically.

Members of the communities had different views about the process, especially regarding the pre-selection phase. In one focus group, for instance, participants stated that 'the leaders know better who are the people in the community that may participate better, ${ }^{73}$ therefore pre-selection was not a bad thing. Yet, in many cases, community members had very critical views about the process. Participants in one focus group, for instance, expressed that in the LCs 'they are only chosen within the structure ${ }^{74}$ and are later presented to the population, so they did not see it as a real choosing process. ${ }^{75}$ Others stated, 'they don't want us to participate because they know we are going to complain.' ${ }^{76}$ Another group further mentioned that the LC members 'elected themselves' to the council at the administrative post (they referred to the continuity of old members); ${ }^{77}$ therefore, in their view it was not a participatory process. These excerpts reflect a critical view of the current modus operandi of the LCs, which does not necessarily correspond to the official narrative.

\section{The dynamics of local representativeness}

A second indicator of the LCs' representativeness vis-à-vis local communities is the extent to which the members engage with the population on a daily basis and their ability to represent the diversity of local interests. As in the case of the selection phase, the fieldwork revealed a series of limitations in this domain. One factor that seems to influence these dynamics is the fact that the creation of the councils came as a national directive-that is, from the top down, instead of being demand-driven. An immediate consequence of this is that many members are still learning what their role should be in this institution, so their posture has been often more reactive rather than proactive. For example, with few exceptions, most LC members interviewed admitted waiting for the meetings to be called by the president of the councils instead of taking the lead in proposing meetings and topics to be discussed. ${ }^{78}$ Moreover, the interviews revealed that more meetings had taken place at the higher echelons of the councils than at the level of the villages, to the point that in some villages the LCs did not seem to properly operate or exist anymore even if they had been created in $2011 .^{79}$ As the village is the district sub-unit closest to the majority of the population, and 
the localities are often very distant from most villages, this constitutes a serious setback to the local representativeness of the councils.

This observation reveals an inherent contradiction in a local body that was ultimately created from the top down: even though the councils are supposed to represent local interests, their members have to learn their function from someone else, e.g., what they should do and which agendas they should discuss. This leads to tricky situations, such as the regular presence of 'guests of honour' (e.g., the chiefs of the locality, traditional leaders, school directors and the chief of the police) invited by the LC presidents of the meetings in order to share knowledge and expertise about certain topics. ${ }^{80}$ Apparently an indicator of community interaction, the role of 'guests of honour' may be a problematic issue. First, they are invited by the president, not by the members of the councils. Second, the very terminology used, guests of honour, carries the implicit connotation that they are somehow special and their opinion has an important influence in shaping the views of the council's members. LC members in a focus group, ${ }^{81}$ for instance, commented that their presence made a difference in the sense of promoting action. As an example, they referred to the case of the repayment of a local credit initiative implemented by the government (the District Development Fund): among other functions, members of the councils have been entrusted with encouraging those who took out the loan to repay it; the fact that the leaders were there to explain the details of how to make the repayment was described as a factor that incited more action from LC members in this particular area. It is noteworthy that this specific example was mentioned: the repayment of loans from the District Development Fund has been a major topic on the national political agenda, and district administrators have strongly pushed members of the councils to act as debt collectors. Thus, and ironically, this example is illustrative of how the council may serve as a body that helps to implement government directives at the local level-as opposed to pressing the government to better attend to local demands.

In this regard, a striking finding of the fieldwork was precisely the very weak interaction between the members of the councils and the local population. Indeed, the interviews revealed a gap between the sense of duty to the meetings that take place at the locality and district levels (and which are called by the LC presidents-local government officials) and the more informal interaction between the LCs and the population (which should be the most important front). There is, in fact, a predominant belief among LC members that 'people know who the LC members are', therefore, when needed, people reach the members of the LCs in order to present their issues. ${ }^{82}$

Remarkably, none of the LC members questioned their ability to represent the community. Yet, the information gathered in the communities showed a much more problematic picture. First, many of the participants interviewed had a very mixed and sometimes limited understanding of what the LCs were and what their general functions were, ${ }^{83}$ and some were not aware of anyone in their own communities who belonged to a council. ${ }^{84}$ Moreover, the general view of the LCs and their work was often critical. In one focus group, for instance, someone referred to the councils as a 'montagem' (a set-up). ${ }^{85}$ They explained that, even though there existed councils in the villages and localities, ultimately, what counted was what took place at the higher levels of the councils because it is not 'just anyone' who reaches the LC at district level but only 'the most influential people of the chiefs' ${ }^{86}$ This view of separation also appeared in other groups. On one occasion, the participants explained that they simply did not speak to the LC because the members think of them (the community) as 
'people from a lower level,' ${ }^{87}$ so they felt they were not heard. Some communities reported interacting with the councils, but, even in these cases, they pointed to the lack of initiative of the LCs to promote interaction with the community ${ }^{88}$ and the lack of any action/feedback regarding the concerns brought to them. ${ }^{89}$ More generally, such views reflected the fact that the councils are often perceived to be linked more with the 'structure'-i.e., the government-than with the community.

The fieldwork also showed that the link between the LCs and the women in the communities was particularly weak. First, there was a huge asymmetry between men and women regarding their knowledge of the LCs as well as their interaction with them. Additionally, the focus groups showed a strong disconnect between the female members of the LCs and the women in the communities. Indeed, even when the women interviewed knew that there should be women in the LCs, many could not identify any women they knew that had positions there..$^{90}$ In some cases, they knew a female member but this was not accompanied by any kind of interaction that could foster women's interests in the district. ${ }^{91}$

To a great extent, the limitations surrounding the councils are directly related to the legal framework that regulates their functioning and the context in which they operate. Even though they are officially presented as the local civil society, their modus operandi is directly influenced by local power dynamics, including the strong role played by community authorities. There is, in fact, a clear contradiction between the operating principles of horizontality that permeate the idea of civil society as envisioned in the liberal peace, and the hierarchical dynamics that sustain the existence of community authorities. Moreover, the fact that these bodies are presided over by a local government authority makes them hybrid institutions that, ultimately, have neither 'government' power, nor constitute a pure expression of civil society, as they have been created from the supply side of the chain, i.e., the government, instead of on demand. This hybrid status further feeds the local perception that they are a species of government, linked to the structure, even though, ultimately, they do not have this kind of power.

\section{Conclusion}

It is the contention of this article that one of the main problems of decentralisation and local governance in Mozambique has to do with the fact that the main policy to promote bottom-up governance dynamics has come from the top down, a problem that pervades peace-building activities more generally, in particular state-building reforms. This contradiction is key because, ultimately, the 'top' is usually interested in retaining power instead of redistributing it, especially in the case of post-war scenarios, where there is still deep mistrust among the main political forces.

As shown, in Mozambique the design of the decentralisation agenda and its emphasis on deconcentration instead of devolution was the result of intense dispute between the political parties, as well as pressure from donors. The dual system and the gradual approach reflected the only possible agreement at the time, an agreement that allowed some degree of change (in particular the creation of a limited number of municipalities), but which also prevented a more radical change from taking place, as it allowed the central government to retain a strong political influence at the local level. In this context, the local councils represent a middle-ground solution that enables the government to claim that local participation is increasing in governance matters, but without compromising the actual power chain, as the 
role of these councils remains consultative and linked to the district administration (which is by default linked to the dominant party) and its ability and will to implement local demands.

It is important to stress that in-depth ethnographic and comparative studies on the local councils in Mozambique are still rare and very much needed. Yet, there is evidence that some of the problems encountered in Angoche are reproduced elsewhere in the country. During the fieldwork leading to this article, I had the chance to speak to members of the community from the districts of Moma and Mogovolas, also in Nampula province, and many of them highlighted similar problems to those found in Angoche. Regarding the process of 'revitalisation' in 2011, they referred to the inability of the technical teams to control what had taken place locally before their arrival and the low level of participation of members of the communities. ${ }^{92}$ They also noticed how many of the new LC members selected were relatives of local chiefs, not people chosen by the community. Some also mentioned that if they disagreed with the process there was little they could do, because the 'LCs are linked to the government, and so we cannot complain to the government. ${ }^{33}$ A member of the DTC of Mogovolas also referred to the problem of the low rate of community participation during the reconstitution process, and admitted that they should have rescheduled the process in several instances, but they were only able to do so in very few cases. ${ }^{94}$ Moving away from Nampula province, Forquilha and Orre, in one of the rare in-depth studies on the matter, and focusing on the pre-2011 period, pointed more critically to the political dynamics of the dominant party in shaping the constitution and the functioning of these bodies in the districts of Zavala, Gorongosa and Monapo, which highly compromised these bodies' representativeness vis-à-vis the local community. ${ }^{95}$

In sum, the evidence available shows that the role of the LCs in Mozambique in representing the communities is still very limited. That said, it is worth asking whether other types of initiatives promoting local governance (not originating from the top down) are flourishing and, if so, if they are performing any better than the LCs. In Angoche, and in other districts in Nampula, one of the most solid initiatives on this front has been the establishment of the local development committees (LDCs) and fora. These bodies emerged in the late 1990s, supported by the Dutch NGO SNV and, later on, the local NGO Akilizetho ADS. ${ }^{96}$ Unlike the LCs, the LDCs were and still are created on demand; that is, local actors decide to set up these bodies and NGOs help them by providing capacity-building on issues in the realm of local governance and development. To a certain extent, the functions of the LDCs resemble those of the LCs: they are expected to identify and discuss any problems that affect their communities, as well as propose activities and initiatives that may contribute to enhancing the wellbeing of the local population; they also engage in participatory activities, which include mobilisation and assistance in areas such as education, calamity prevention and health. The main difference between LCs and LDCs is that the latter is a bottom-up initiative and they do not include any local government authorities amongst their members.

A thorough analysis of the LDCs would require another article, however, I would like to highlight three issues regarding the role of these bodies in the dynamics of local governance. These observations stem from my participation in two bi-district conferences held in 2012 by Akilizetho with members of LDCs, which aimed to assess this NGOs' work with these bodies and their effectiveness in the previous 12 years in the districts of Angoche, Mogincual, Moma and Mogovolas. ${ }^{97}$

First, even though the LDCs have flourished from the bottom up instead of the top down, they are nonetheless still subject to a series of structural and local constraints that limit 
their ability to influence local governance. At the local level, their existence is sometimes viewed with suspicion by community authorities and even LC members, who see them as competitors trying to 'steal their power' instead of partners. This is the case even when members of LDCs are also members of LCs. In fact, because the LDCs are generally exposed to more workshops for capacity development than the LCs, sometimes these members are marginalised within the LCs. ${ }^{98}$ In other words, LDCs cannot fully escape the vertical power dynamics that exist locally and this affects their ability to influence local matters.

Second, the functioning of the LDCs as a more 'Westernised' civil society body faces limitations because of the different context and mentality that prevails at the local level. So, whereas in the West civil society is predominantly perceived as a counterweight to the government, in the case of the LDCs, many members expressed the perceived need to actually engage with and involve more government authorities in their activities so they could be more effective. In a context where civil society is underfunded and the government has historically been the main provider of basic needs, including jobs, this is not surprising. Ironically, this is partly the logic that is at the heart of the LCs. The challenge for LDCs, in this regard, is to increase their ability to influence local governance-including by co-operating with the local government-while retaining their independence as a civil society body.

Finally, and surprisingly, one of the findings of the conference was the fact that, over the years, as members of the LDCs gained more knowledge through their interactions with NGOs, they also partly distanced themselves from the community, becoming a small 'elite' at the local level. As a consequence, and even though they were originally an expression of bottom-up dynamics, in some cases they started having difficulties in maintaining local engagement in some of their activities. So, whereas many LDCs endured over the years and many new ones were set up, others ceased to exist.

In summary, looking at the broader picture, there is no doubt that Mozambique has come a long way since the end of the war. However, after 23 years, it is time to reconsider the extent to which decentralisation and local governance reforms have contributed to the enhancement of democratisation and local representation. The analysis in this article has shown that many of the reforms implemented had the double function of both allowing and preventing change at the same time: in essence, there has been change in the formal domain of the policy agenda; nevertheless, these reforms have not fundamentally changed the dynamics of local representation, at least not in the sense of instigating substantial critical and conscious forms of political participation, or even creating local demand for more participation in political spaces at the local level. Initiatives such as the LDCs have the potential to do that, but their ability to accomplish this is also dependent on the same structural factors that affect the effectiveness of the LCs. Perhaps the question to be asked is whether it is more efficient to simply put resources where demand already exists (e.g., supporting local organised civil society and LDCs), instead of trying to invent new social structures. But then again, maybe this is not what the 'top' wants after all.

\section{Notes}

1. The full research is part of the author's PhD thesis: Maschietto, 'The Contradictions of Empowerment'.

2. Olowu and Wunsh, Local Governance, 4-5; see also Europe Aid, 'Supporting Decentralisation'.

3. Crawford and Hartmann, 'Introduction: Decentralisation', 9, quoting Manor. Fiscal decentralisation is often considered a third type of decentralisation; however, the authors 
see the latter as a crosscutting element of deconcentration and devolution. It should be noted that this article does not engage in the discussion on federalism, a form of decentralisation on which a lot has been written, but which is very specific and not the main focus of liberal peace-building.

4. Europe Aid, 'Supporting Decentralisation'.

5. Menkhaus, 'Local Governance and Peacebuilding'.

6. Ramsbotham et al., Contemporary Conflict Resolution, 30 .

7. For a comprehensive view of the liberal peace debate, see Newman et al., New Perspectives.

8. Kauzya, 'Decentralisation'; Europe Aid, 'Supporting Decentralisation'; UNDP, 'Local Governance, Peacebuilding'; Brinkerhoff, 'State Fragility and Governance'; Heijke and van den Berg, 'Dynamics between Decentralisation'.

9. Jackson, 'Local Government'; Crawford and Hartmann, 'Introduction: Decentralisation'; Schou and Haug, 'Decentralisation in Conflict'.

10. Brinkerhoff, 'Rebuilding Governance'; Braathen and Hellevik, 'The Role of Decentralisation'.

11. Jackson, 'Local Government'; Crawford and Hartmann, 'Introduction: Decentralisation'.

12. Schou and Haug, 'Desentralisation in Conflict'; Jackson, 'Local Government'.

13. UNDP/ECA, 'Local Governance', 10; Crook, 'Decentralisation and Poverty Reduction'; Heijke and van den Berg, 'Dynamics between Decentralisation'; Crawford and Hartmann, 'Introduction: Decentralisation'; Brinkerhoff, 'Rebuilding Governance'.

14. UNDP/ECA, 'Local Governance'; Kauzya, 'Decentralisation'; Crawford and Hartmann, 'Introduction: Decentralisation'.

15. Kauzya, 'Decentralisation'.

16. Crawford and Hartmann, 'Introduction: Decentralisation'; Jackson, 'Local Government'.

17. UNDP/ECA, 'Local Governance'; Crook, 'Decentralisation and Poverty Reduction'; Olowu and Wunsh, Local Governance.

18. Olowu and Wunsh, Local Governance.

19. UNDP/ECA, 'Local Governance', 13.

20. Crook, 'Decentralisation and Poverty Reduction'.

21. Crawford and Hartmann, 'Introduction: Decentralisation'; Jackson, 'Local Government'.

22. Olowu and Wunsh, Local Governance; see also UNDP/ECA, 'Local Governance'; Crawford and Hartmann, 'Introduction: Decentralisation'; Brinkerhoff, 'State Fragility and Governance.'

23. Olowu and Wunsh, Local Governance.

24. Crawford and Hartmann, 'Introduction: Decentralisation'.

25. Boone, Political Topographies.

26. Crawford and Hartmann, 'Introduction: Decentralisation'; see also comparison between the cases of Ghana and Uganda in Awortwi, 'An Unbreakable Path?'.

27. Awortwi, 'An Unbreakable Path?'.

28. Ibid.

29. Reaud and Weimer, 'USAID Mozambique'.

30. Lundin, 'An Analytical Reading.'

31. Ibid.; Buur and Kyed, 'New Sites of Citizenship'.

32. Buur and Kyed, 'New Sites of Citizenship'; Lundin, 'An Analytical Reading'; West and KloeckJenson, 'Betwixt and Between'.

33. Buur and Kyed, 'Contested Sources of Authority'.

34. Bornstein, 'Planning and Peacebuilding'.

35. Weimer, 'Para uma Estratégia'.

36. Ibid.; Braathen and Jørgensen, 'Democracy without People?'.

37. Bornstein, 'Planning and Peacebuilding.'

38. Weimer, 'Para uma Estratégia'.

39. Ibid.

40. Bornstein, 'Planning and Peacebuilding'; Weimer, 'Para uma Estratégia'.

41. Braathen and Jørgensen, 'Democracy without People?'; Lundin, 'An Analytical Reading'; Weimer, 'Para uma Estratégia'.

42. Reaud and Weimer, 'USAID Mozambique'. 
43. Weimer, 'Para uma Estratégia', 77.

44. Confidential source, Central Government, Maputo, 1 June 2012.

45. Bornstein, 'Planning and Peacebuilding.

46. Meneses and Santos, 'Mozambique: The Rise'; Reaud and Weimer, 'USAID Mozambique'; Weimer, 'Para uma Estratégia'.

47. Nuvunga, 'Tendências nas Eleições'.

48. Joseph Hanlon, Mozambique News Reports \& Clippings, no. 282, 19 March 2015. Available at: http://www.open.ac.uk/technology/mozambique/news-reports-2015-0 [Accessed 19 March 2015].

49. In 2013, a new law was passed creating 13 new districts and transforming all provincial capitals in districts. Mozambique Information Agency (AIM), 'Moçambique Passa a Ter 13 Novos Distritos', 21 March 2013. Available at http://www.portaldogoverno.gov.mz/noticias/ governacao/marco-2013/mocambique-passa-a-ter-13-novos-distritos/ [Accessed 23 May 2014].

50. In 2009 this initiative was transformed into the District Development Fund.

51. This project was built upon a pre-existing United Nations Capital Development Fund (UNCDF) project in that province in partnership with the National Directorate of Budget and Planning and with support from the government of the Netherlands and the UNDP.

52. Borowczak and Weimer, 'Andar com a Bengala'; Macuane et al., 'Entre o Estado'.

53. Rep. of Moz., Decree 11/2005., Art. 111.

54. Rep. of Moz., Diploma Ministerial 67/2009, Art. 6.

55. Ibid., Art. 7.

56. Ibid., Art. 118.

57. Buur and Kyed, 'New Sites of Citizenship'.

58. Buur and Kyed, 'Contested Sources of Authority'.

59. Interview, female member of the LC, Angoche, 22 April 2012; focus group, three members of a LC, Angoche, 19 April 2012.

60. Interview, member of the DTC, Angoche, 7 May 2012.

61. Interviews with: male member of a LC, Namaponda, 16 April 2012; female member of a LC, Aúbe, 24 April 2012; male member of a LC, Canhaua, 27 April 2013. Focus group with men from the community, Muparrea, 16 April 2012.

62. Interview with female member of a LC, Luaze, 29 April 2013.

63. Focus group with three members of the district LC, Angoche, 19 April 2012.

64. Interviews with: two members of a LC, Nametoria, 13 April 2012; male member of a LC, Namaponda, 16 April 2012; female member of a LC, Aúbe, 24 April 2012. Focus groups with: mixed members of the community, Nacopa, 15 May 2012 and Matipa, 15 May 2012.

65. Data obtained from reports from the district administration of Angoche.

66. Data obtained at the Mozambican Official Statistics Database (INE). Available at http://www.ine.gov.mz/ [Accessed 10 August 2014].

67. Interviews with four members of the DTC, Angoche, 16 April, 6 and 7 May 2012.

68. Interviews with two members of the DTC, Angoche, 23 April and 6 May 2012.

69. Interview with member of the DTC, Angoche, 23 April 2012.

70. Interview with member of the DTC, Angoche, 14 May 2012.

71. Forquilha, 'Reformas da Descentralização'; Forquilha and Orre, 'Conselhos Locais e Institucionalização'

72. Interview with member of the DTC, Angoche, 23 April 2012.

73. Focus group with mixed members of the community, Nacopa, 15 May 2012.

74. The word 'the structure' was often repeated in the focus groups and interviews. Its connotation stands somewhere between the idea of 'the party' (Frelimo) and the 'local government' (as those with power to make decisions).

75. Focus group with men from the community, Namaponda, 16 April 2012.

76. Focus group with members of a rural association, Napuala, 17 April 2012.

77. Focus group with mixed members of the community, Sanjale, 15 May 2012. 
78. Interviews with: two members of a LC, Nametoria, 13 April 2012; chief of the Administrative Post, Namaponda, 16 April 2012; male member of a LC, Namaponda, 16 April 2012; female member of a LC, Angoche, 22 April 2012.

79. Focus groups with: mixed members of the community, Cirozine, 11 April 2012; men from the community, Nacucha, 12 April 12.

80. Interviews with: two members of a LC, Nametoria, 13 April 2012; chief of the locality, Mutucuti, 17 April 2012. Focus group with men from the community and two members of LCs, Siretene, 24 April 2012.

81. Focus group with men from the community and two members of local councils, Siretene, 24 April 2012.

82. Focus groups with: two male members of a LC, Geba, 18 April 2012; three members of the district LC, Angoche, 19 April 2012; two members of a LC, Nacuculo, 24 April 2012. Interview with female member of a LC, Angoche, 22 April 2012.

83. Interview with two members of a LC, Nametoria, 13 April 2012. Focus groups with women from the community, Namaponda, 16 and 17 April 2012.

84. Focus group with women from the community, Geba, 18 April 2012.

85. Focus groups with mixed members of the community, Cirozine, 11 April 2012.

86. Ibid.

87. Focus group with men from the community, Namaponda, 16 April 2012.

88. Focus group with mixed members of the community, Sanjale, 15 May 2012.

89. Ibid.; focus group with mixed members of the community, Matipa, 15 May 2012.

90. Focus groups with: women from the community, Nacucha, 12 April 12; mixed members of the community, Nacopa, 15 May 2012; mixed members of the community, Matipa, 15 May 2012.

91. Focus groups with: women from the community, Namaponda, 16 and 17 April 2012; Geba, 18 April 2012; mixed members of the community, Sanjale, 15 May 2012.

92. Focus group, men from the community, from the districts of Moma and Mogovolas, Moma, 10 May 2012.

93. Ibid.

94. Interview with member of the technical commission of the district of Mogovolas, Moma, 11 May 2012.

95. Forquilha and Orre, 'Conselhos Locais'.

96. SNV stands for Stichting Nederlandse Vrijwilligers (Foundation of Netherlands Volunteers), as established in 1965. Since 1993 its official name is SNV Netherlands Development Organisation.

97. These views reflect my personal analysis and summary of the event; I do not intend to reproduce the official view of Akilizetho.

98. Focus group, men from the community, from the districts of Moma and Mogovolas, Moma, 10 May 2012.

\section{Acknowledgements}

The research leading to this article was conducted while the author was a doctoral candidate at the Department of Peace Studies, University of Bradford and would not have been possible without the support of Akilizetho ADS and its team in Nampula, in particular Pedro Carvalho and Acita. I am also extremely grateful to all those who took part of this research, to Prof Neil Cooper for his feedback on previous versions of this article, as well as to the anonymous reviewers for their valuable comments on my original submission.

\section{Notes on Contributor}

Roberta Holanda Maschietto has a PhD in Peace Studies from the University of Bradford and is currently a post-doctoral researcher at the Centre for Social Studies, University of Coimbra. 


\section{ORCID}

Roberta Holanda Maschietto (D) http://orcid.org/0000-0002-6079-280X

\section{References}

Awortwi, Nicholas, 2011. 'An Unbreakable Path? A Comparative Study of Decentralization and Local Government Development Trajectories in Ghana and Uganda'. International Review of Administrative Sciences 77(2), 347-377.

Boone, Catherine, 2003. Political Topographies of the African State. Territorial Authority and Institutional Choice. Cambridge University Press, New York.

Bornstein, Lisa, 2008. 'Planning and Peacebuilding in Post-War Mozambique: From Narratives to Practices of Development'. Journal of Peacebuilding and Development 4(1), 1-15.

Borowczak, W. and B. Weimer, 2012. 'Andar com a Bengala Emprestada Revisitado: o Apoio Internacional à Descentralização em Moçambique, 1995-2011 [Walking with a Borrowed Walking Stick Revisited: International Support to Decentralisation in Mozambique, 1995-2011]'. In Moçambique: Descentralizar o Centralismo. Economia Política, Recursos e Resultados [Mozambique: Decentralising Centralism. Political Economy, Resources and Results], ed. B. Weimer. IESE, Maputo, 103-162.

Braathen, Einar and Siri Bjerkreim Hellevik, 2006. 'The Role of Decentralisation on Peace Making and Conflict. A Literature Review'. NIBR Working Paper, no. 125. Norwegian Institute for Urban and Regional Research, Blindern.

Braathen, E. and B. Jørgensen, 1998. 'Democracy without People? Local Government Reform and 1998 Municipal Elections in Mozambique'. Lusotopie, 31-38.

Brinkerhoff, Derick W., 2005. 'Rebuilding Governance in Failed States and Post-Conflict Societies: Core Concepts and Cross-Cutting Themes'. Public Administration and Development 25, 3-14.

Brinkerhoff, Derick W., 2011. 'State Fragility and Governance: Conflict Mitigation and Subnational Perspectives'. Development Policy Review 29(2), 131-153.

Buur, Lars and Helene Maria Kyed, 2006. 'Contested Sources of Authority: Re-claiming State Sovereignty by Formalizing Traditional Authority in Mozambique.. Development and Change 37(4), 847-869.

Buur, Lars and Helene Maria Kyed, 2006. 'New Sites of Citizenship: Recognition of Traditional Authority and Group-based Citizenship in Mozambique'. Journal of Southern African Studies $32(3), 563-581$.

Crawford, Gordon and Christof Hartmann, 2008. 'Introduction: Decentralisation as a Pathway out of Poverty and Conflict?'. In Decentralisation in Africa: A Pathway out of Poverty and Conflict?, eds. G. Crawford and C. Hartmann. Amsterdam University Press, Amsterdam, 7-32.

Crook, Richard C., 2003. 'Decentralisation and Poverty Reduction in Africa: The Politics of LocalCentral Relations'. Public Administration and Development 23, 77-88.

Europe Aid, 2007. 'Supporting Decentralisation and Local Governance in Third Countries'. Tools and Methods Series. Reference Document, no. 2. European Commission, Brussels.

Forquilha, Salvador C., 2010. 'Reformas de Descentralização e Redução da Pobreza num Contexto de Estado Neo-Patrimonial. Um Olhar a Partir dos Conselhos Locais e o OIIL Em Moçambique [Decentralisation Reforms and Poverty Reduction in the Context of Neo-Patrimonial State. A Look from the Perspective of the Local Councils and the OIIL in Mozambique]'. In Pobreza, Desigualdade e Vulnerabilidade em Moçambique [Poverty, Inequality and Vulnerability in Mozambique], ed. L. de Brito, C.N. Castel-Branco, S. Chichava and A. Francisco. IESE, Maputo, 19-48.

Forquilha, S.C. and A. Orre, 2012. 'Conselhos Locais e Institucionalização Democrática em Moçambique [Local Councils and Democratic Institutionalisation in Mozambique]'. In Moçambique: Descentralizar o Centralismo. Economia Política, Recursos e Resultados [Mozambique: Decentralising Centralism. Political Economy, Resources and Results], ed. B. Weimer. IESE, Maputo, 330-353. 
Heijke, M. and D. van den Berg, 2011. 'Dynamics between Decentralisation and Peace Building' Discussion Paper. IKV Pax Christi and VNG. Available at: http://www.kpsrl.org/browse/ download/t/dynamics-between-decentralisation-and-peace-building [Accessed 17 August 2012].

Jackson, Paul, 2014. 'Local Government in Post-Conflict Contexts: An Updated Discussion Paper'. Unpublished paper.

Kauzya, John-Mary, 2005. 'Decentralization: Prospects for Peace, Democracy and Development'. Discussion Paper. Division for Public Administration and Development Management, Department of Economic and Social Affairs, United Nations. Available at: http://unpan1.un.org/intradoc/ groups/public/documents/un/unpan021510.pdf [Accessed 7 January 2015].

Lundin, I.B., 2002. 'An Analytical Reading of the Social Spaces that Mozambique has Opened to Accommodate and Cultivate Peace'. In Mozambique. 10 Years of Peace, ed. B. Mazula. CEDE, Maputo, 101-142.

Macuane, J.J., P. Salimo, D.M. do Rosário and B. Weimer, 2012. 'Entre o Estado, Amakhas, Ampamelas, Landins e ONGs: Relações Sociais, História, Política, Centralização e Descentralização em Nampula [Between the State, Amakhas, Ampamelas, Landins and NGOs: Social Relations, History, Politics, Centralisation and Decentralisation in Nampula]'. In Moçambique: Descentralizar o Centralismo. Economia Politica, Recursos e Resultados [Mozambique: Decentralising Centralism. Political Economy, Resources and Results], ed. B. Weimer. IESE, Maputo, 238-276.

Maschietto, Roberta H., 2015. 'The Contradictions of Empowerment Promotion through Social Engineering. Mozambique's Peace and the "7 Million” Initiative'. PhD diss., University of Bradford.

Meneses, Maria Paula and B. de S. Santos, 2009. 'Mozambique: The Rise of a Micro Dual State'. Africa Development 34(3-4), 129-166.

Menkhaus, Ken, 2014. 'Local Governance and Peacebuilding: Challenges of Legitimate Representation'. Accord 25, 74-77.

Newman, E., R. Paris and O.P. Richmond (eds.), 2009. New Perspectives on Liberal Peacebuilding. United Nations University Press, Tokyo.

Nuvunga, Adriano, 2012. 'Tendências nas Eleições Municipais de 1998, 2003 e 2008 [Tendencies in Municipal Elections in 1998, 2003 and 2008]'. In Moçambique: Descentralizar o Centralismo. Economia Política, Recursos e Resultados [Mozambique: Decentralising Centralism. Political Economy, Resources and Results], ed. B. Weimer. IESE, Maputo, 281-299.

Olowu, D. and J.S. Wunsch, 2004. Local Governance in Africa. The Challenges of Democratic Decentralization. Lynne Rienner, Boulder, CO.

Ramsbotham, Oliver, T. Woodhouse and H. Miall, 2007. Contemporary Conflict Resolution. 2nd edn. Polity, Cambridge.

Reaud, B.A. and B. Weimer, 2010. 'USAID Mozambique Decentralization Assessment'. Report prepared for the United States Agency for International Development, Washington, DC.

Republic of Mozambique Council of Ministers, 2005. Decree 11/2005, Regulação da Lei dos Órgãos Locais de Estado [Regulation of the Law of the Local State Organs]. Republic Bulletin, I Series, no. 23, 2nd Supplement. Maputo, 10 June.

Republic of Mozambique. Ministry of State Administration/Ministry of Planning and Development (MAE/MPD), 2009. Diploma Ministerial 67/2009. Guião sobre Organização e Funcionamento dos Conselhos Locais [Ministerial Diploma 67/2009. Guidelines for the Organisation and Functioning of the Local Councils]. Maputo, 17 April.

Schou, Arild and Marit Haug, 2005. 'Decentralisation in Conflict and Post-Conflict Situations'. NIBR Working Paper, no. 139. Norwegian Institute for Urban and Regional Research, Blindern.

United Nations Development Programme (UNDP), 2010. 'Local Governance, Peace Building and State Building in Post-Conflict Settings.' Discussion Paper. Available at: www.uncdf.org/gfld/docs/ post-conflict.pdf [Accessed 12 June 2015].

United Nations Development Programme/Economic Commission for Africa (UNDP/ECA), 2002. 'Local Governance for Poverty Reduction in Africa'. Fifth Africa Governance Forum (AGF-V) Concept Paper. UNDP/ECA, Maputo.

Weimer, Bernhard, 2012. 'Para Uma Estratégia de Descentralização em Moçambique: "Mantendo a Falta de Clareza?”: Conjunturas, Críticas, Caminhos, Resultados [For a Strategy of Decentralisation in Mozambique: "Keeping the Lack of Clarity?": Conjectures, Critiques, Paths, Results]'. In 
Moçambique: Descentralizar o Centralismo. Economia Política, Recursos e Resultados [Mozambique: Decentralising Centralism. Political Economy, Resources and Results], ed. B. Weimer. IESE, Maputo, 76-102.

West, Harry G. and Scott Kloeck-Jenson, 1999. 'Betwixt and Between: “Traditional Authority" and Democratic Decentralization in Post-War Mozambique’. African Affairs 98, 455-484. 